J. Asiat. Soc. Bangladesh, Sci. 45(1): 71-91, June, 2019

\title{
FLORISTIC STUDY IN LALPUR UPAZILA OF NATORE DISTRICT, BANGLADESH: IDENTIFICATION, DISTRIBUTION AND ECONOMIC POTENTIAL
}

\author{
M. OLIUR RAHMAN*, SHARIKA HASSAN AND MOMTAZ BEGUM \\ Department of Botany, University of Dhaka, Dhaka-1000, Bangladesh
}

\begin{abstract}
Floristic study in Lalpur Upazila of Natore district has identified 216 species distributed in 173 genera and 72 families, of which Magnoliopsida (Dicotyledons) is represented by 188 species under 147 genera and 60 families, while Liliopsida (Monocotyledons) is constituted by 28 species under 26 genera and 12 families. In Magnoliopsida, Asteraceae is the largest family represented by 16 species, whereas in Liliopsida, Poaceae is the largest family consisting of 8 species. The genus Solanum is the largest in Magnoliopsida, whereas Cyperus is the largest genus in Liliopsida. Habit analysis reveals that herbs are represented by 118 species $(55 \%)$, shrubs by 32 species $(15 \%)$, trees by 50 species $(23 \%)$ and climbers by 16 species $(7 \%)$. Potential of the angiospermic flora has been recognized by the occurrence of 57 medicinal plant species which are used over 30 diseases for the primary health care of the local people of Lalpur Upazila. Though the study area is floristically rich, some plant species are under threats. The rare and medicinally as well as economically important species to this area need to be conserved through both in-situ and ex-situ approaches for sustainable development.
\end{abstract}

Key words: Angiosperms, Floristics, Medicinal plants, Conservation, Natore

\section{Introduction}

The importance of floristic studies has been recognized by the Conference of Parties, i.e. the signatory countries of the Convention of Biological Diversity (CBD). As a consequence of the process of implementing the Convention on Biological Diversity, the need for taxonomic knowledge as a means of underpinning biodiversity conservation is now widely accepted by governments (Heywood 2004).

The development and sustainable use of the plant resources of a country is dependent on a thorough knowledge of the flora. Sustainable use of botanical resources can play an important role in the economy of the country. The account of the flora of Bangladesh so far done is inadequate compared to the estimated huge floral diversity of the country. Considering the present pace of destruction of the forests, wetlands and the general habitats, there is an imminent danger of loosing a number of plant species even before

*Author for correspondence: <oliur.bot@du.ac.bd>. 
they are identified and studied. To save the species from further annihilation, urgent exploration is necessary, firstly to record what all genetic resources we have, to explore their potential and to identify those that are threatened so that proper measures may be undertaken to conserve them.

Lalpur Upazila of Natore district lies between $24.07^{\prime}$ and 24.18' $\mathrm{N}$ and between 88.52' and 89.08' E, with an area of 327.92 sq. $\mathrm{km}$. The Upazila is bounded on the north by Bagatipara and Baraigram Upazilas and Ishwardi, Bheramara and Daulatpur (Kushtia) Upazilas on the south and Daulatpur, Bheramara Upazilas on the east and Bagha Upazila on the west. Lalpur Upazila consists of 10 unions, namely Lalpur, Arbab, Kadamchilan, Gopalpur, Duaria, Durduaria, Walia, Bilmaria, Salampur, Chandhupail (Fig. 1).

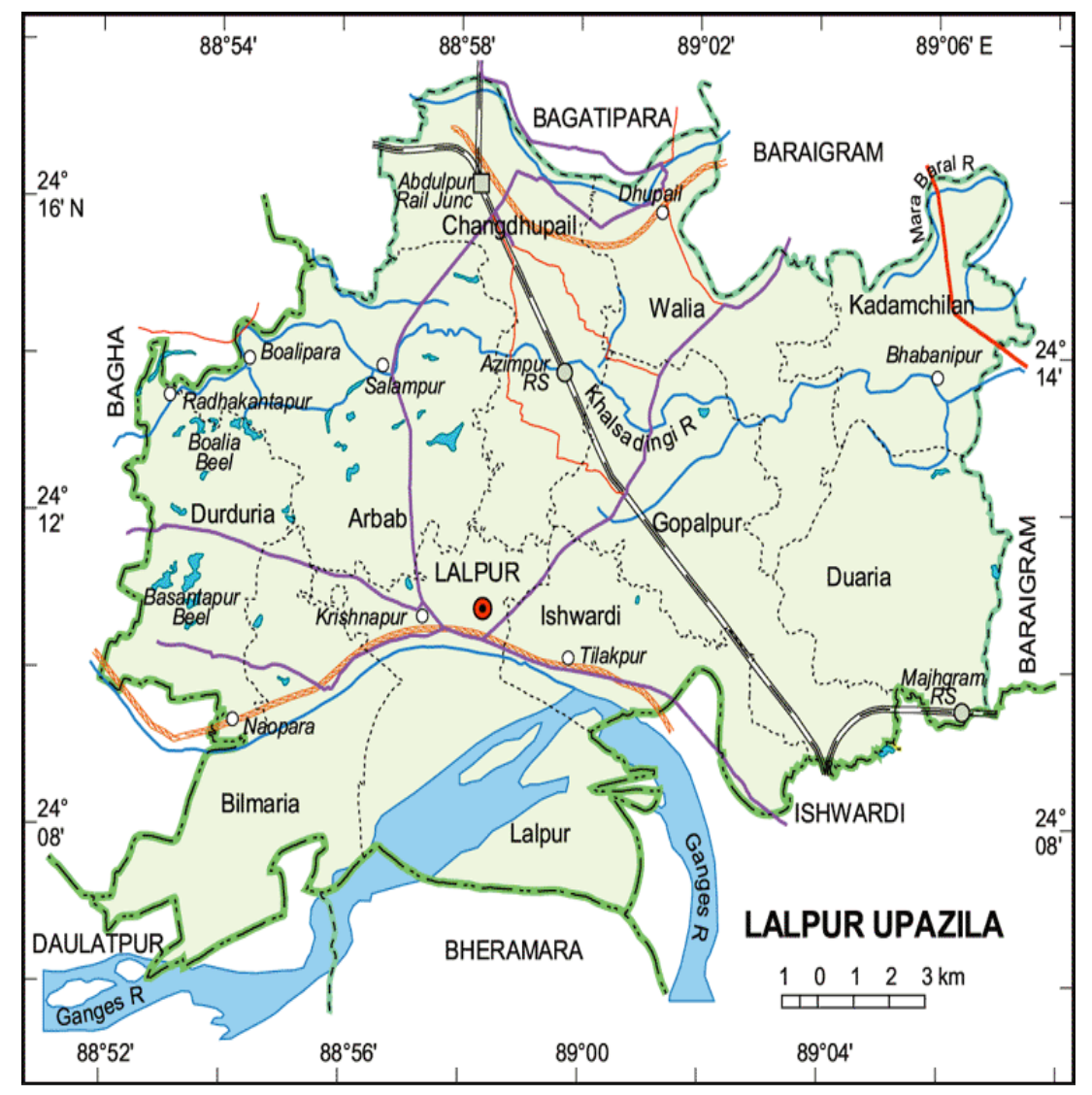

Fig. 1. Map of Lalpur Upazila showing the sampling sites of different unions (Source: https://photos.wikimapia.org/p/00/02/59/14/29_full.gif). 
The significance of studying floristic diversity has been acknowledged and carried out in Bangladesh since last few decades (Khan 1972-1987, Khan and Banu 1972, Khan and Hassan 1984, Khan and Rahman 1989-2002). Recently, several floristic and biodiversity studies in different areas and Upazilas of Bangladesh have been done (Khan et al. 1994, Rahman and Hassan 1995, Khan and Huq 2001, Tutul et al. 2010, Rahman and Alam 2013, Rahman et al. 2012, 2013). However, no attention has been paid on the flora of Lalpur Upazila and its potential has never been assessed. Therefore, there is dire need to explore, identify, document and conserve the plant wealth of the area for betterment of mankind especially those plant resources which are used for primary healthcare. The objectives of the present study are three-folds, viz., (i) to explore and identify the angiosperms of Lalpur Upazila of Natore district with their distributional abundance, (ii) to determine the potential of the plant species, particularly the medicinal plants, and (iii) to investigate the threatened species and suggest their conservation measures.

\section{Materials and Methods}

Five botanical expeditions from March, 2017 to April, 2018 were made to collect plant specimens from Lalpur Upazila covering all seasons. Collected specimens were processed using standard herbarium techniques (Hyland 1972), and identified by experts, consultation of standard literature, and matching with herbarium specimens deposited at both Dhaka University Salar Khan Herbarium and Bangladesh National Herbarium. The descriptions were compared with Hooker (1872-1897), Khan (1972-1987), Dassanayake and Fosberg (1980-1991) and Khan and Rahman (1989-2002). The updated nomenclature of the species has been cited following Ahmed et al. (2008-2009), Siddique et al. (2007), Rashid and Rahman (2011, 2012), The Plant List (2013), Rahman and Hassan (2017) and TROPICOS (2017). Status of occurrence of the species has been determined on the basis of field observation. Common names of the species are based on Huq (1986), and interview with the local people. The potential uses of the species including the medicinal plants have been recorded through interviews with the local people of the area, and from the relevant literature (van Valkenburg and Bunyapraphatsara 2002, Yusuf et al. 2009). Each species is supplemented by its local name, family name, habit, habitat, flowering and fruiting period, distribution, and potential uses.

\section{Results and Discussion}

The present study has identified 216 angiosperm taxa from Lalpur Upazila of Natore district, which belong to 173 genera and 72 families. The identified taxa along with their local name, family name, habit, habitat, flowering and fruiting time, distributional 
abundance, and potential use are presented in Table 3. Magnoliopsida (Dicots) is represented by 188 taxa under 137 genera and 60 families, while Liliopsida (Monocots) is constituted by 28 taxa under 26 genera and 12 families. Magnoliopsida constitute $85 \%$ while Liliopsida covers $15 \%$ of the total identified taxa.

The numbers of angiosperm taxa recognized under 72 families show variation. The family Asteraceae is the largest family in Magnoliopsida represented by 16 species, followed by Euphorbiaceae with 10 taxa. Some other large families include Solanaceae (9 taxa), Cucurbitaceae and Fabaceae (8 taxa each), Caesalpiniaceae (7 taxa), and Acanthaceae and Malvaceae (6 taxa each). In Liliopsida, Poaceae appears as the largest family bearing 8 taxa, followed by Cyperaceae with 5 taxa. Ten dominant families of the study area are shown in Fig. 2 along with their number of genera and species.

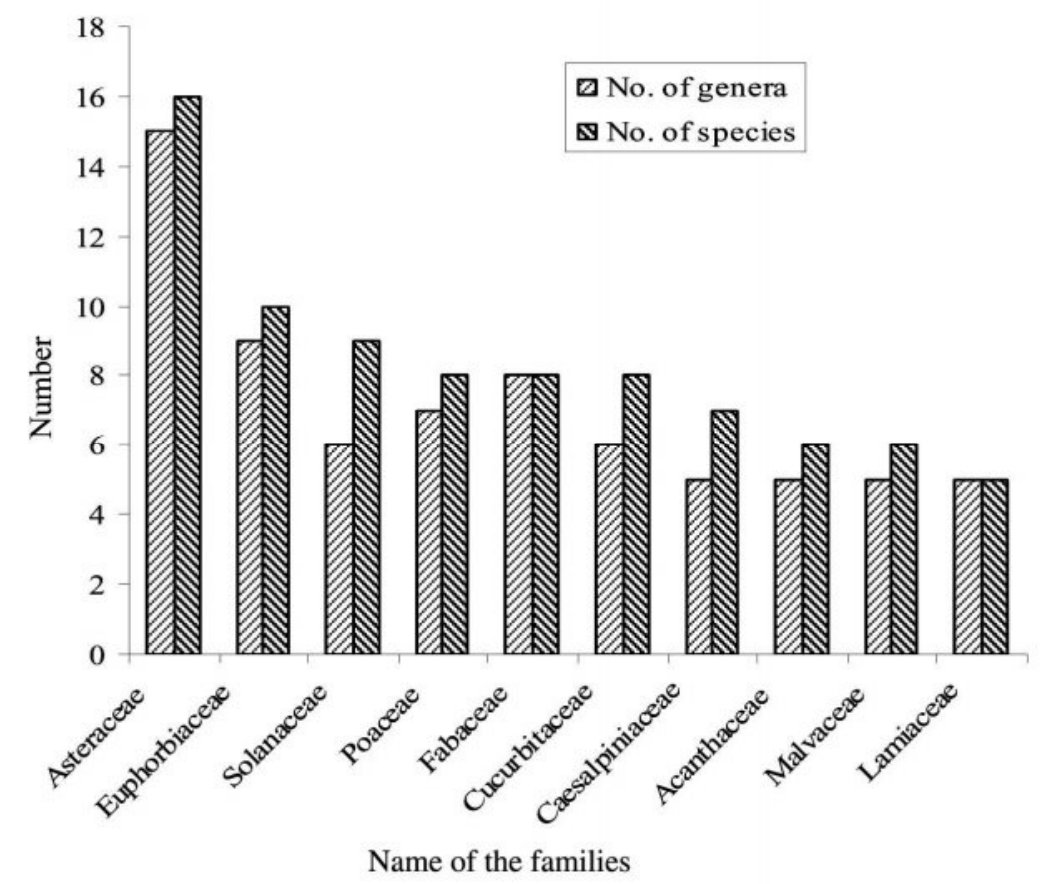

Fig. 2. Ten largest angiosperm families of Lalpur Upazila showing number of genera and species.

Ten dominant families found in Lalpur Upazila comprise 83 species that represent about $38 \%$ of the total species identified, while the remaining 62 families with a total 133 species represent $62 \%$ of the total. Twenty-three families in Magnoliopsida are represented by a single species in the present investigation. 


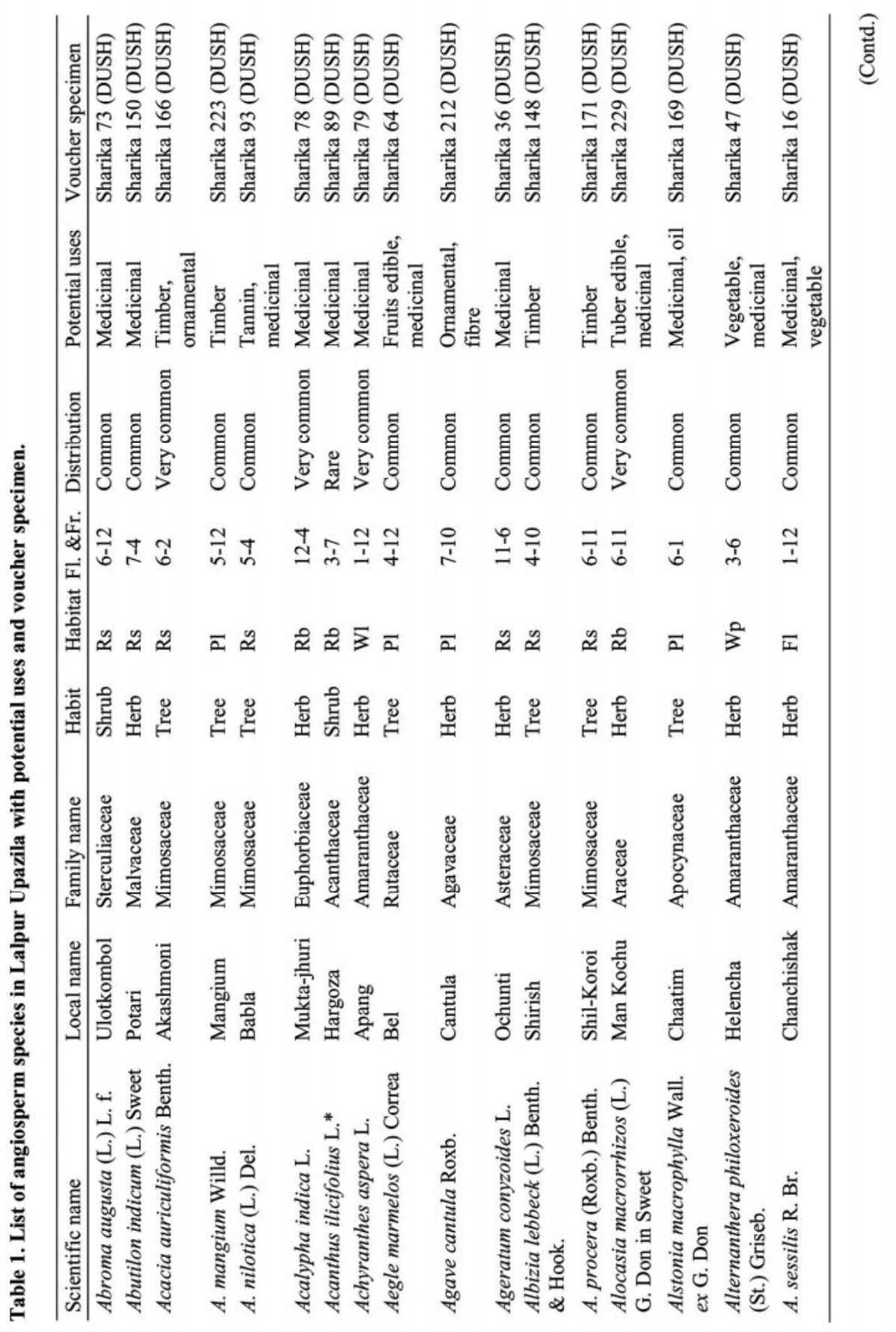




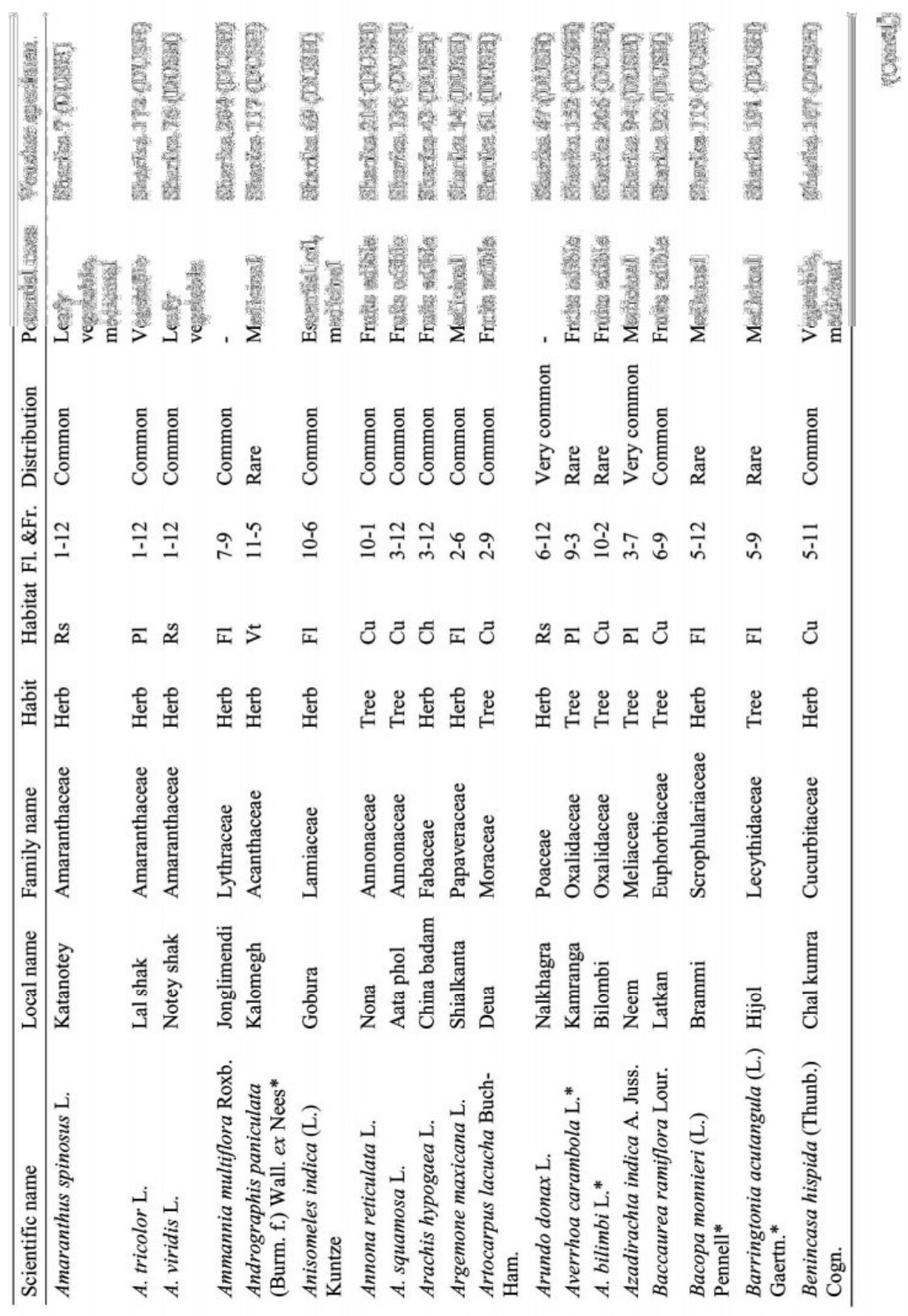


Floristic study in Lalpur Upazila of Natore district

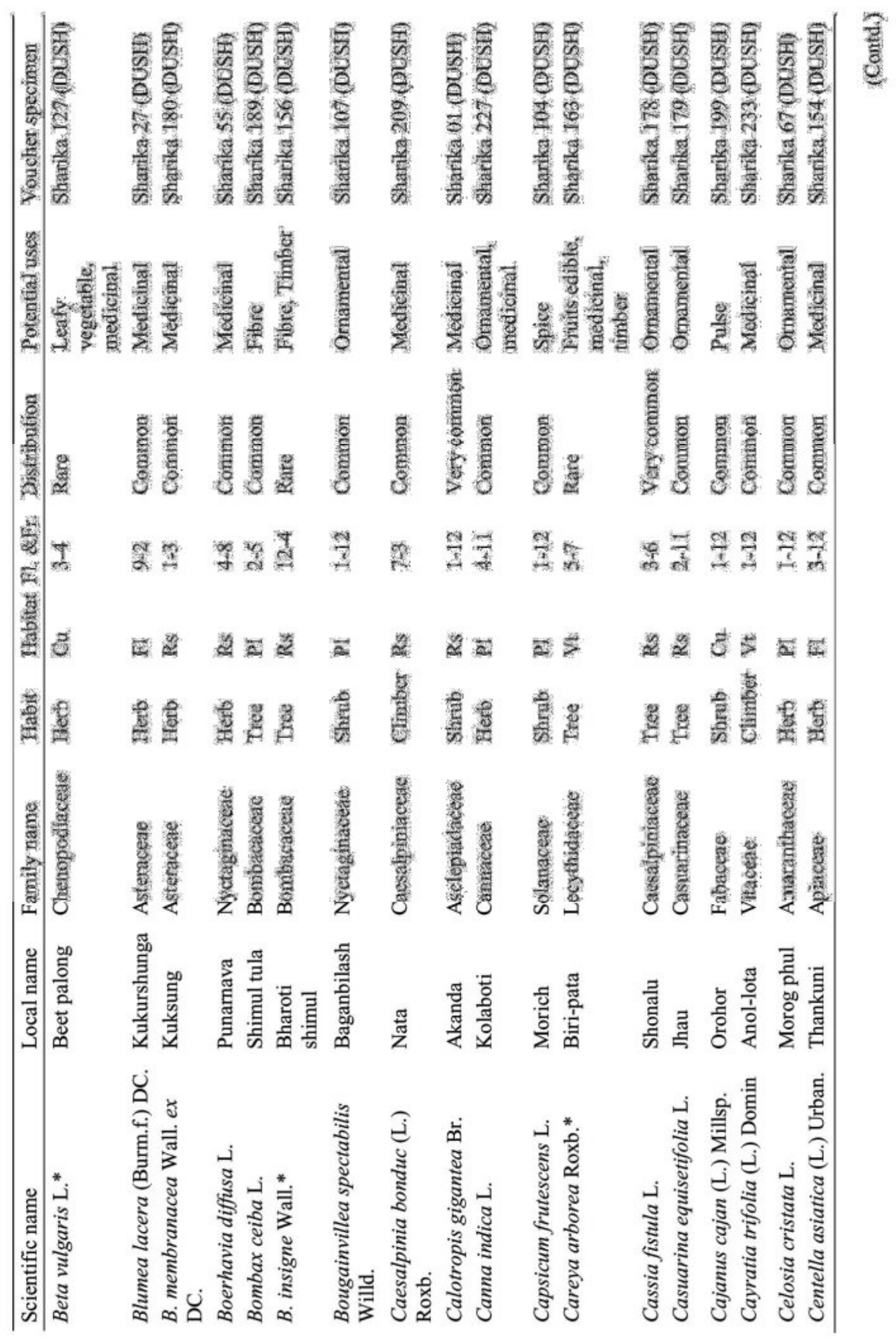




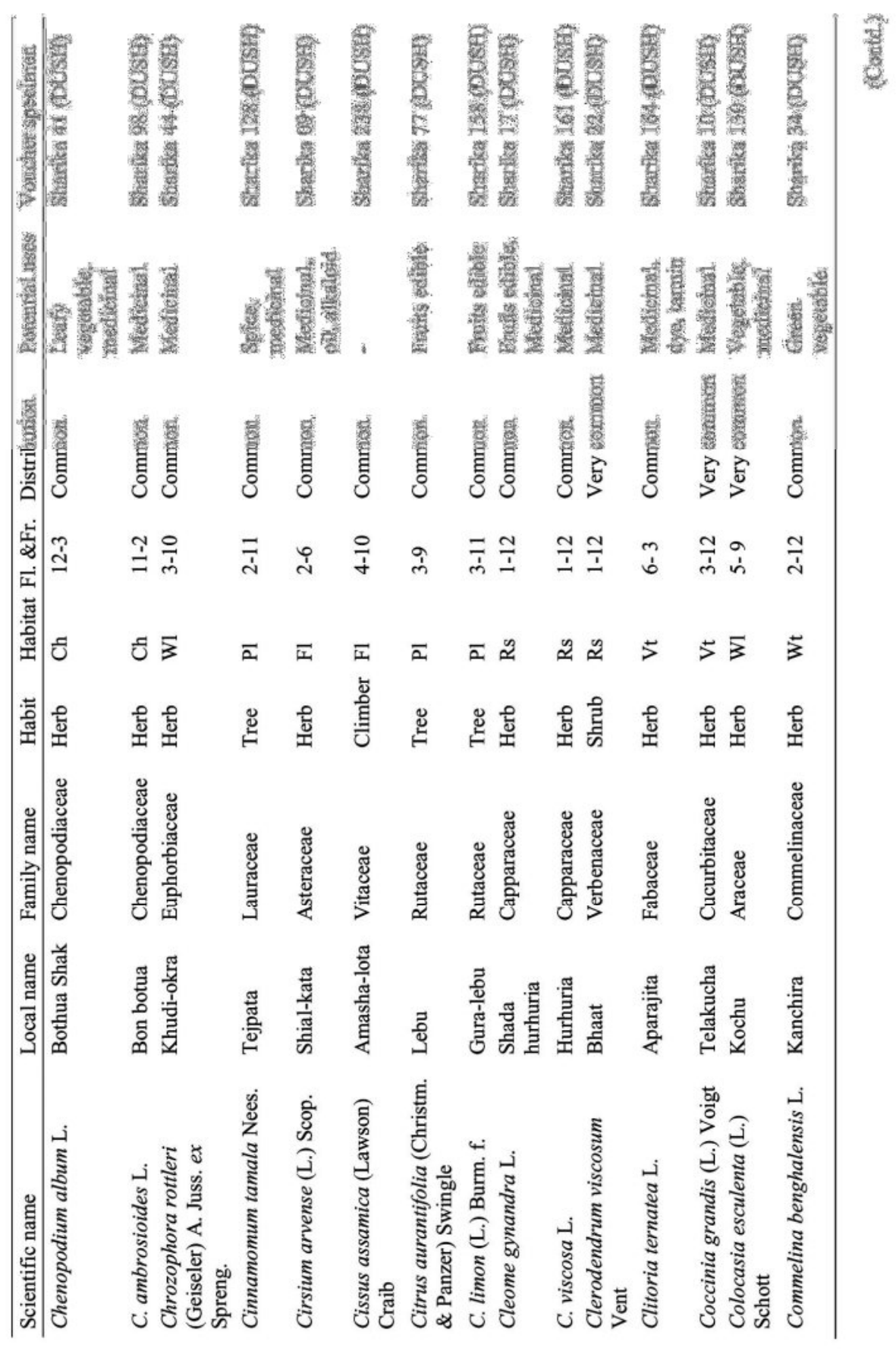




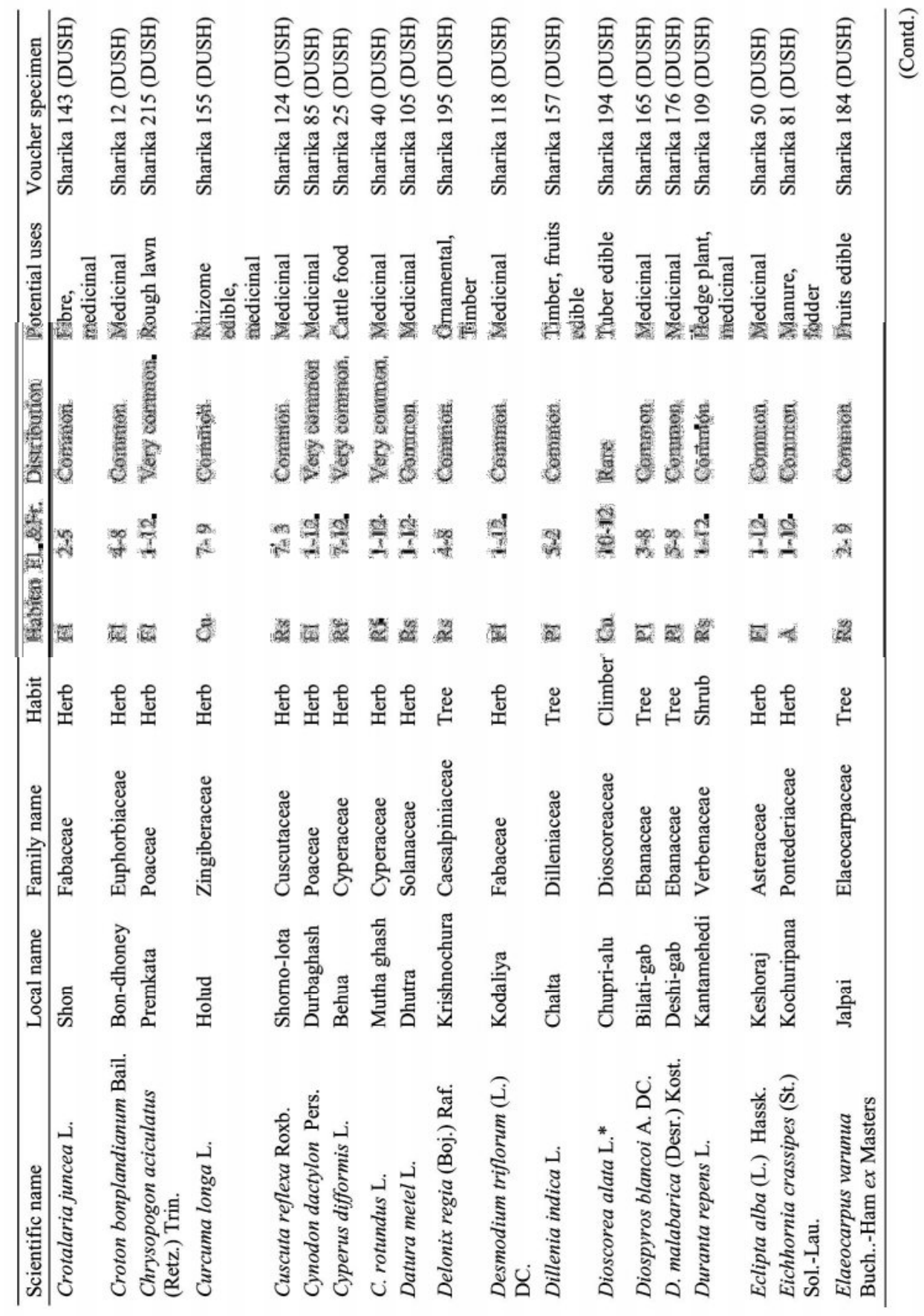




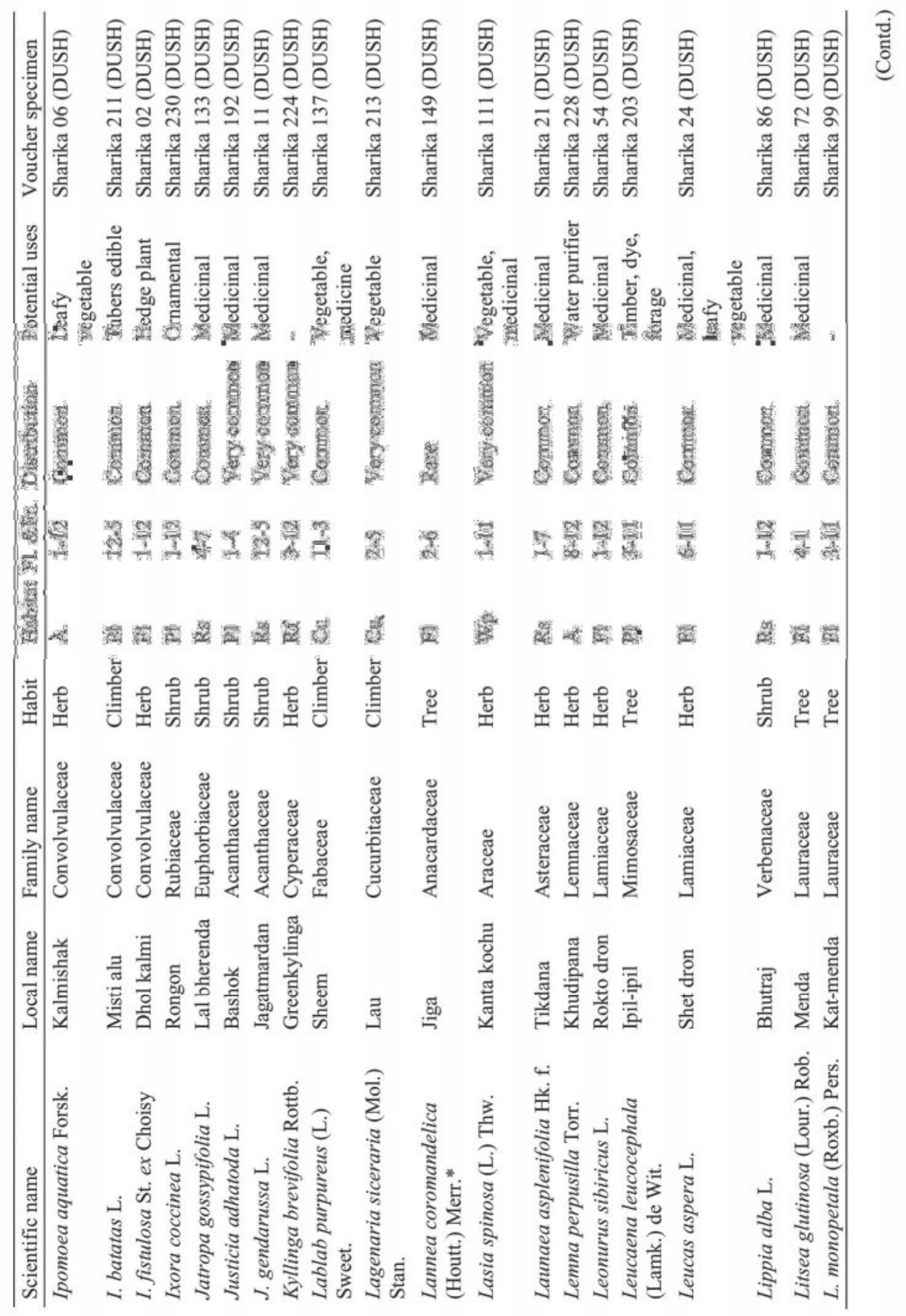




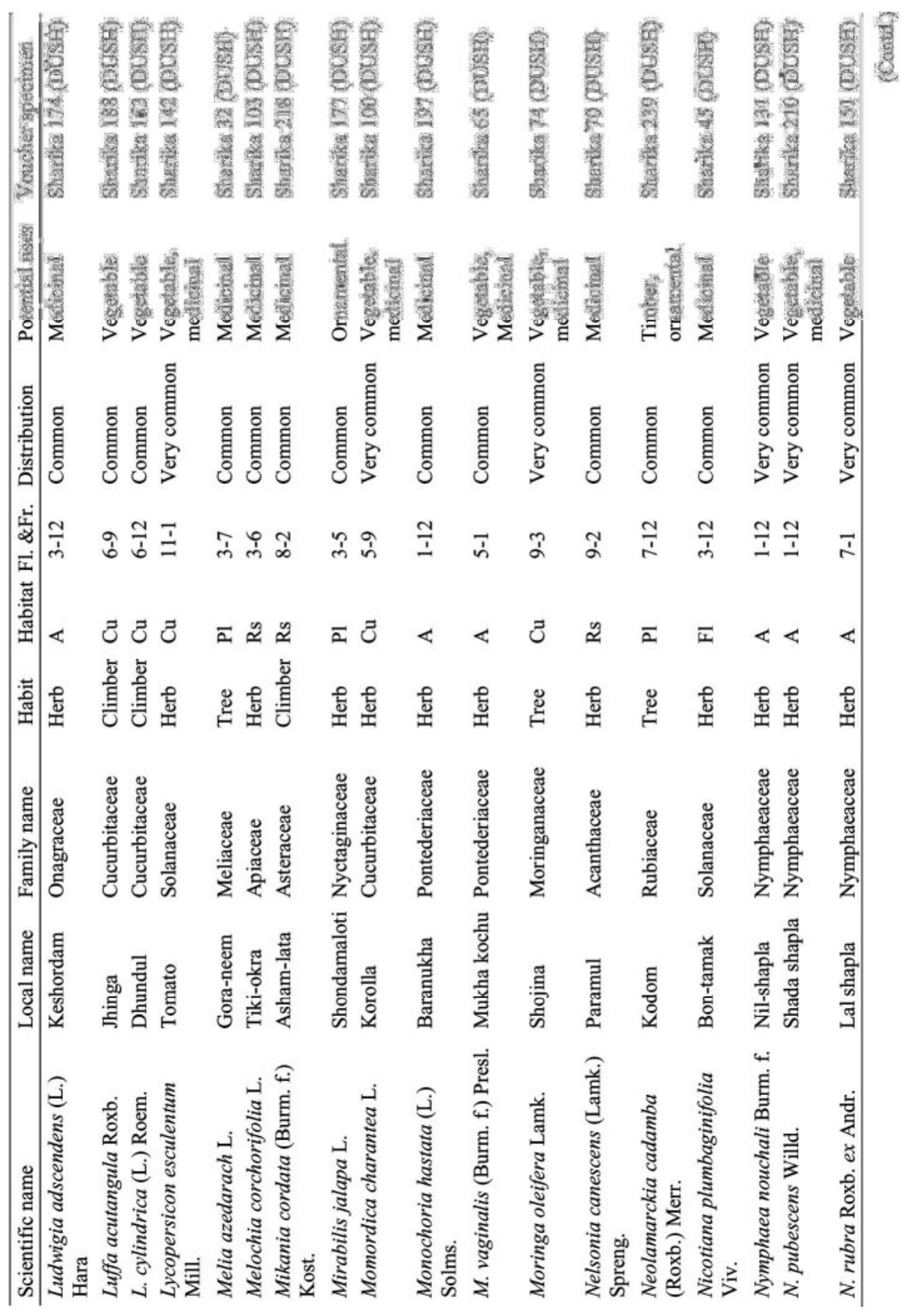


Floristic study in Lalpur Upazila of Natore district

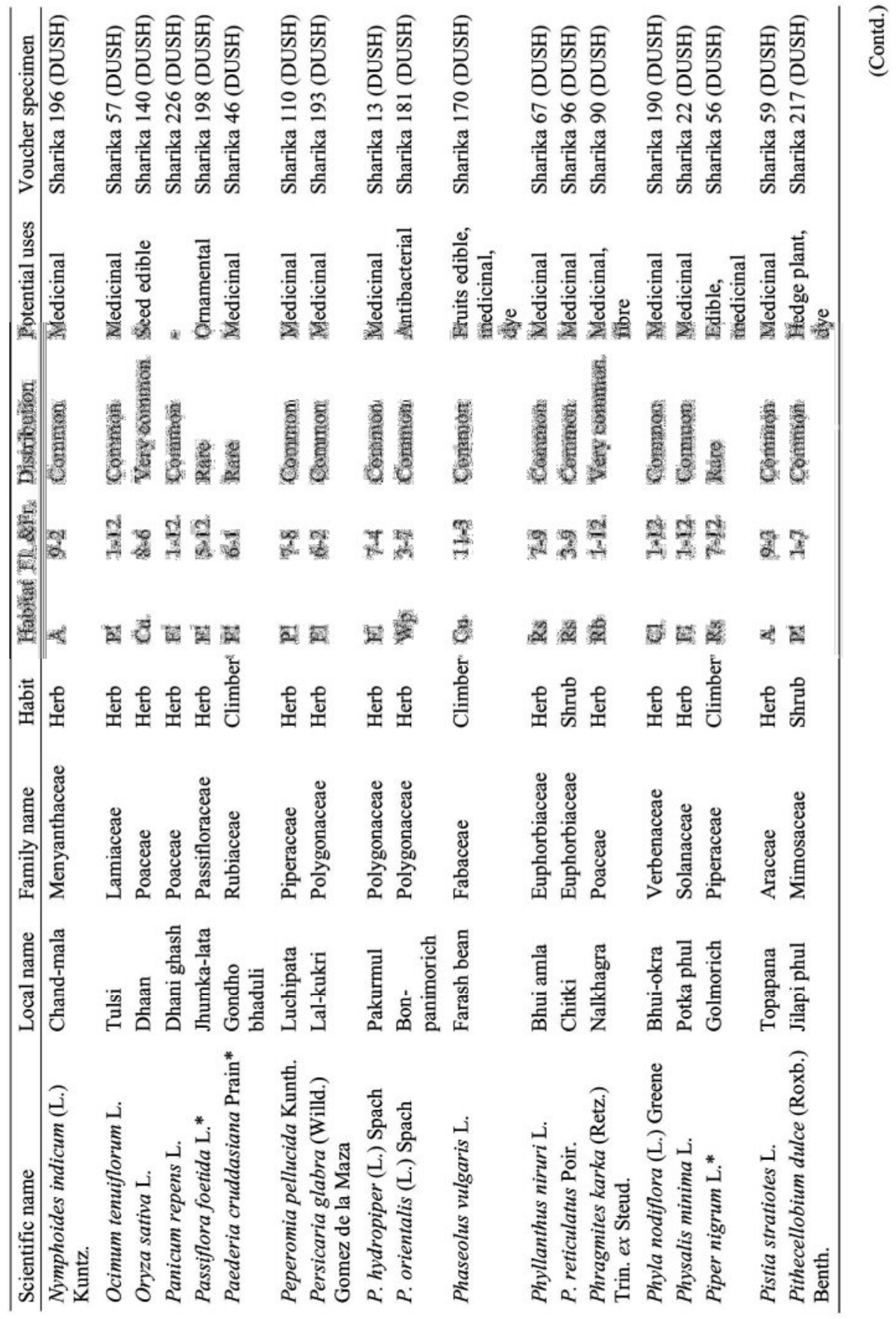




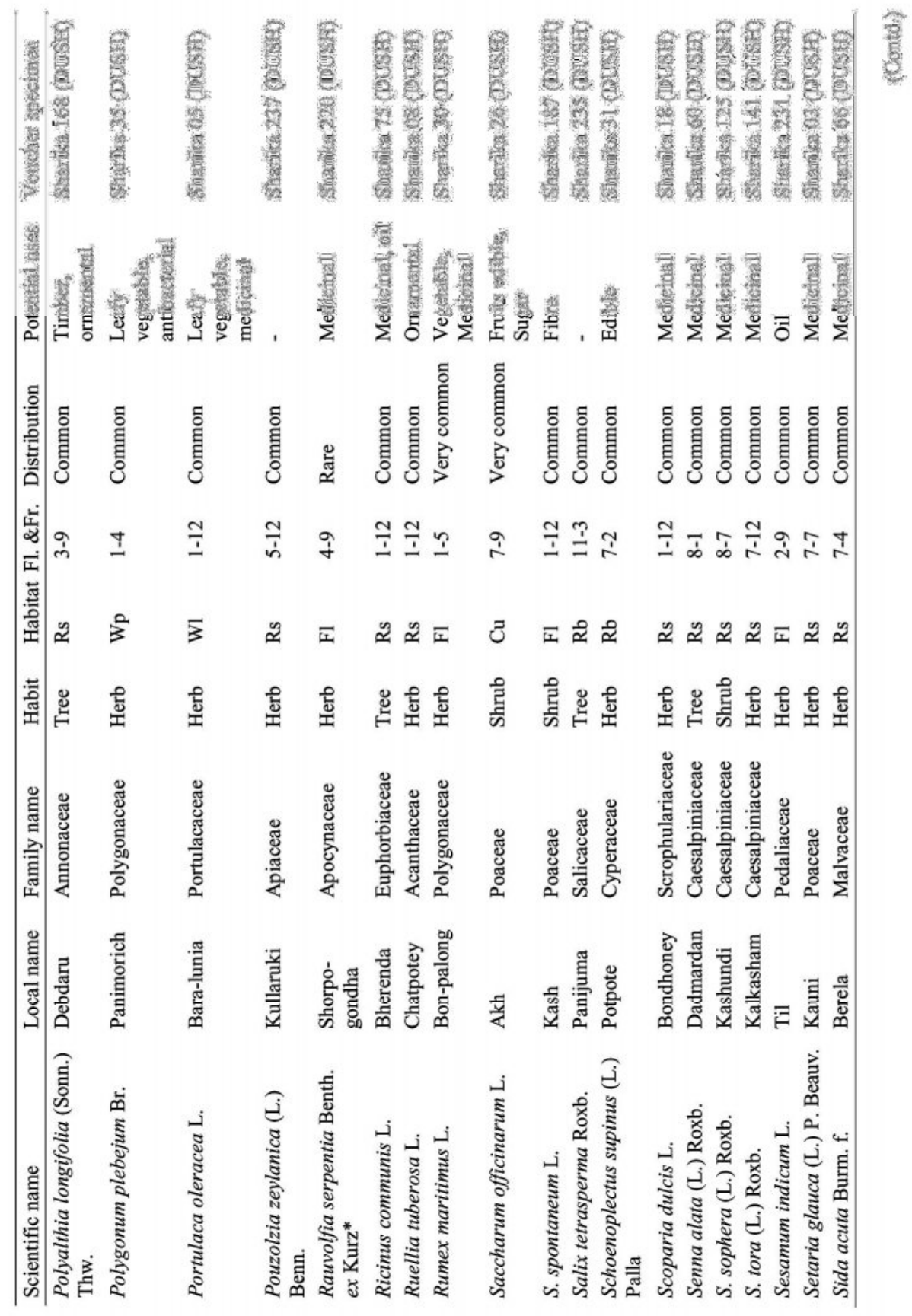


Floristic study in Lalpur Upazila of Natore district

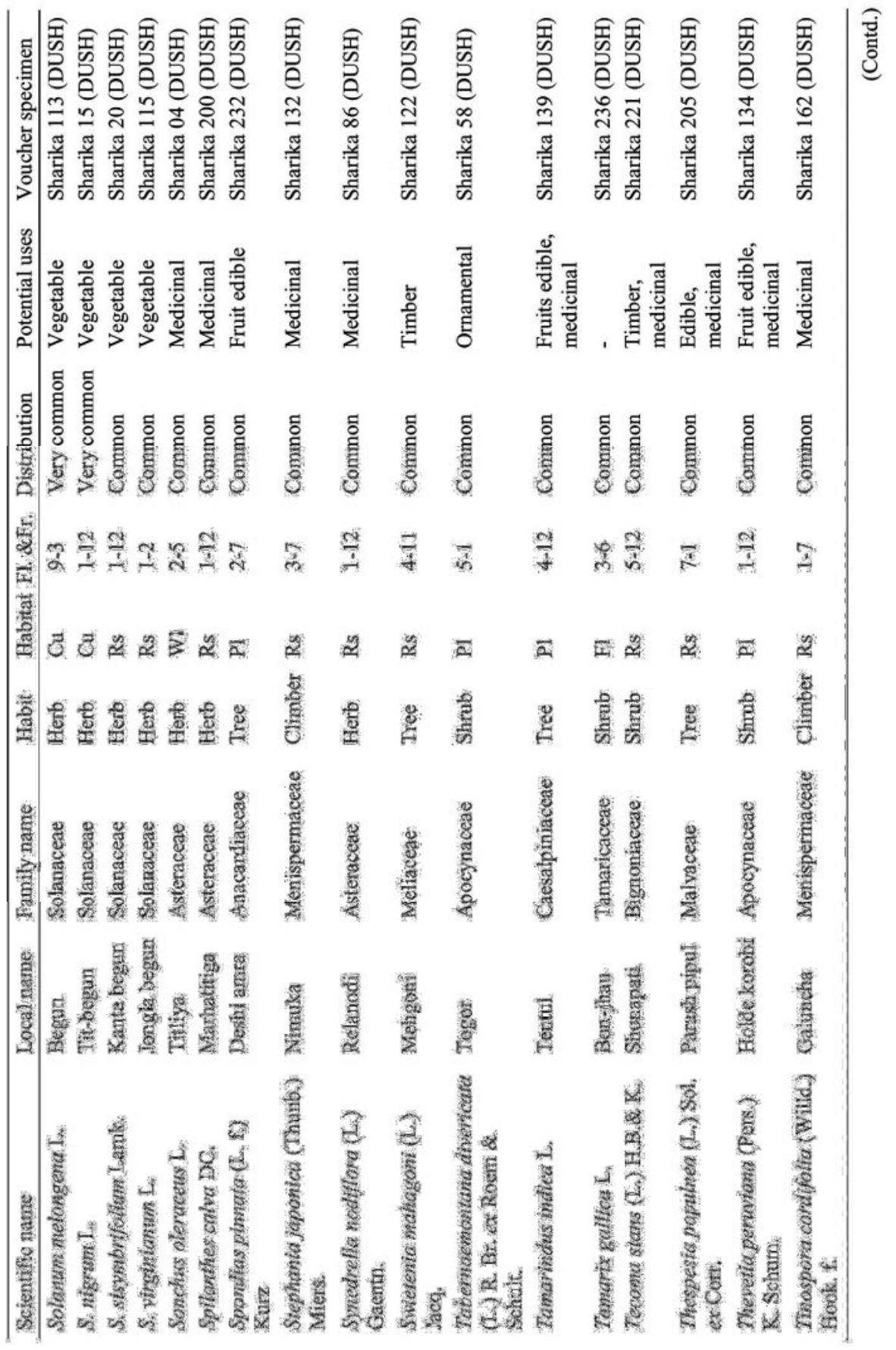




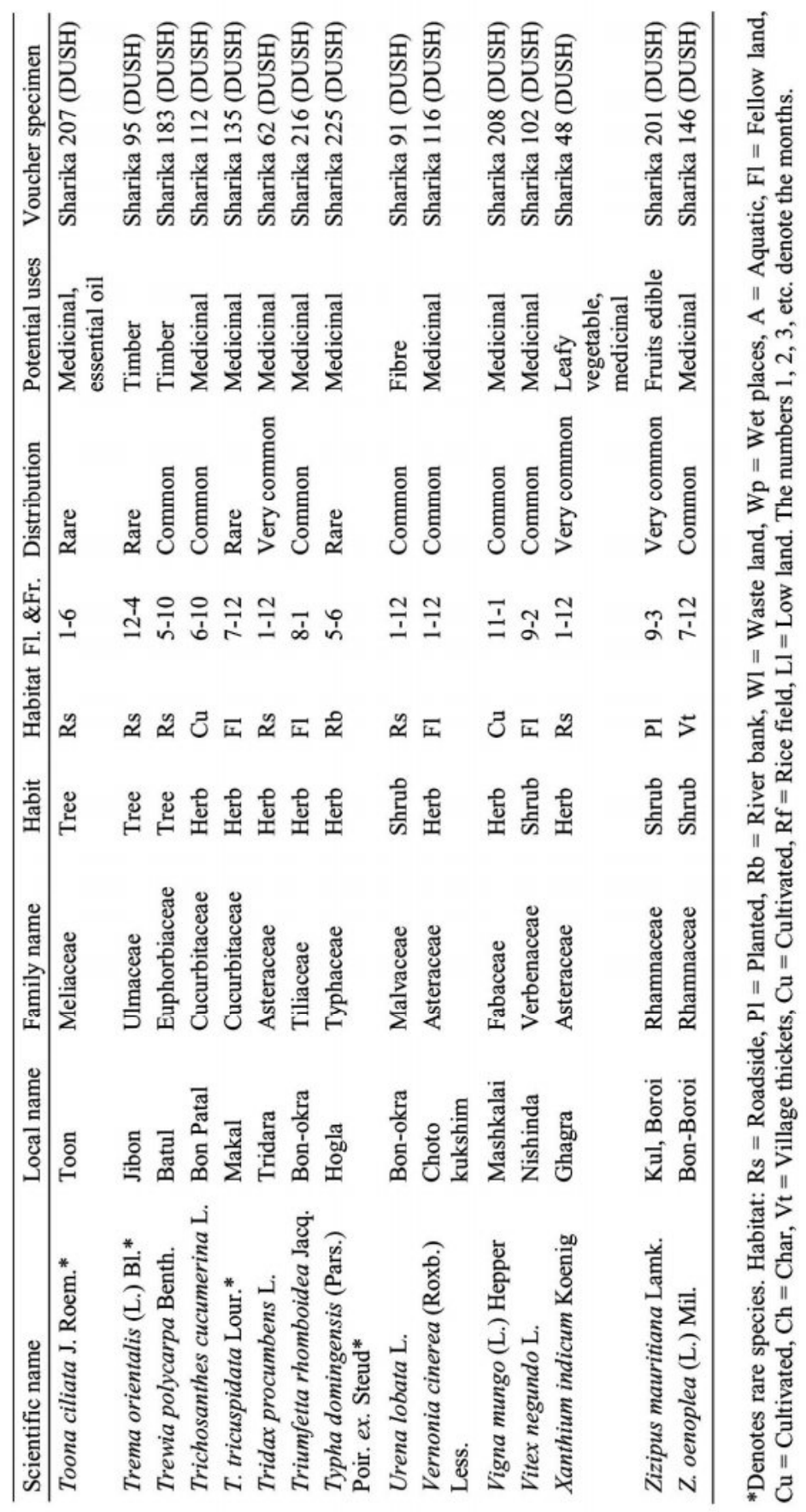


Floristic study in Lalpur Upazila of Natore district

Medicinal Plants: The present study has identified 57 medicinal plants used by the local people of Lalpur upazila for their primary healthcare which are used for treatment of over 30 ailments (Table 2).

Table 2. Medicinal plants used by local people of Lalpur Upazila for primary healthcare.

\begin{tabular}{|c|c|c|c|c|}
\hline Scientific name & Family name & Local name & Part(s) used & Medicinal uses \\
\hline Achyranthes aspera & Amaranthaceae & Apang & Root & Jaundice, Pain \\
\hline Aegle marmelos & Rutaceae & Bel & Fruit & Dysentery, Constipation \\
\hline Ageratum conyzoides & Asteraceae & Akunti & $\begin{array}{l}\text { Root, stem, } \\
\text { leaf }\end{array}$ & Wound, Sores \\
\hline Albizia lebbeck & Mimosaceae & Shirish & Bark & Cancer, Bronchitis, Asthma \\
\hline Alstonia macrophylla & Apocynaceae & Chaatim & Bark & Chronic diarrhoea \\
\hline $\begin{array}{l}\text { Alternanthera } \\
\text { philoxeroides }\end{array}$ & Amaranthaceae & Helencha & Whole plant & Constipation, Indigestion \\
\hline A. sessilis & Amaranthaceae & Chanchi Shak & Whole plant & Indigestion, Snake bite \\
\hline Amaranthus spinosus & Amaranthaceae & Kantanotey & Whole plant & Chest pain \\
\hline A. viridis & Amaranthaceae & Noyte shak & Whole plant & Snake-bite \\
\hline Azadirachta indica & Meliaceae & Neem & Leaf & $\begin{array}{l}\text { Scabies, Menstruation, } \\
\text { Diabetes }\end{array}$ \\
\hline Blumea lacera & Asteraceae & Kukurshunga & Flower, leaf & $\begin{array}{l}\text { Stomach-ache, Rheumatic } \\
\text { fever }\end{array}$ \\
\hline Calotropis procera & Asclepiadaceae & Akand & $\begin{array}{l}\text { Leaf, flower, } \\
\text { twig }\end{array}$ & Hernia, Rheumatic pain \\
\hline Cassia fistula & Caesalpiniaceae & Sonalu & $\begin{array}{l}\text { Seed, leaf, } \\
\text { flower }\end{array}$ & Constipation, Diabetes \\
\hline Centella asiatica & Apiaceae & Thankuni & Whole plant & $\begin{array}{l}\text { Dysentery, Brain tonic, } \\
\text { Fever }\end{array}$ \\
\hline Citrus limon & Rutaceae & Lebu & Fruit & Fever, Appetizer \\
\hline $\begin{array}{l}\text { Clerodendrum } \\
\text { viscosum }\end{array}$ & Verbanaceae & Bhaat & Leaf, root & $\begin{array}{l}\text { Scabies, Diabetes, } \\
\text { Rheumatism }\end{array}$ \\
\hline Coccinia grandis & Cucurbitaceae & Telakucha & Leaf & Diabetes \\
\hline Colocasia esculenta & Araceae & Kachu & Corm, leaf & Blood purifier, Brain tonic \\
\hline $\begin{array}{l}\text { Commelina } \\
\text { benghalensis }\end{array}$ & Commelinaceae & Dhol pata & Whole plant & Itching, Urinary burning \\
\hline Croton bonplandianus & Euphorbiaceae & Kanchira & Leaf, seed & Eczema \\
\hline Curcuma longa & Zingiberaceae & Holud & Rhizome & Blood purifier \\
\hline Cuscuta reflexa & Cuscutaceae & Swarna-lata & Stem & Jaundice, Diabetes \\
\hline Cynodon dactylon & Poaceae & Durba & Whole plant & Diaphoretic and antipyretic \\
\hline Cyperus rotundus & Cyperaceae & Mutha ghas & Root & $\begin{array}{l}\text { Dyspepsia, Urinary } \\
\text { concretions }\end{array}$ \\
\hline Dillenia indica & Dilleniceae & Chalta & Fruit & Diarrhoea, Dysentery \\
\hline Eclipta alba & Asteraceae & Kashoraj & Whole plant & $\begin{array}{l}\text { Fever, Leucoderma, Hair } \\
\text { tonic }\end{array}$ \\
\hline Euphorbia hirta & Euphorbiaceae & Dudhia & Whole plant & Cough, Bronchitis \\
\hline
\end{tabular}

(Contd.) 


\begin{tabular}{|c|c|c|c|c|}
\hline Scientific name & Family name & Local name & Part(s) used & Medicinal uses \\
\hline Ficus benghalensis & Moraceae & Bot & Bark, leaf & Diabetes, Impotence \\
\hline F. hispida & Moraceae & Dumur & Fruit & Tonic \\
\hline F. religiosa & Moraceae & Aswathwa & Bark & Skin disease \\
\hline Glycosmis pentaphylla & Rutaceae & Datmajon & Leaf, stem & Dysentery, Jaundice, Fever \\
\hline Hyptis suaveolens & Lamiaceae & Tokma & Root, leaf & Constipation, Skin disease \\
\hline $\begin{array}{l}\text { Ichnocarpus } \\
\text { frutescens }\end{array}$ & Apocynaceae & Loi lata & Root, leaf & Fever, Skin disease \\
\hline Justicia adhatoda & Acanthaceae & Basak & Root & Diarrhoea \\
\hline Lannea coromandelica & Anacardiaceae & Jiga & Bark, leaf & Chicken pox \\
\hline Leucas aspera & Lamiaceae & Shetodrone & Whole plant & Arthritic pain \\
\hline Litsea monopetala & Lauraceae & Kat menda & Bark & Pain, Silkworm \\
\hline Ludwigia adscendens & Onagraceae & Mulsi shak & Whole plant & Dysentery \\
\hline Mikania cordata & Asteraceae & Assam lata & Leaf & Cut injury \\
\hline Momordica charantea & Cucurbitaceae & Karola & Fruit, leaf & Diabetes, Blood pressure \\
\hline $\begin{array}{l}\text { Neolamarckia } \\
\text { cadamba }\end{array}$ & Rubiaceae & Kadam & $\begin{array}{l}\text { Stem bark, } \\
\text { leaf }\end{array}$ & Body pain \\
\hline Ocimum tenuiflorum & Lamiaceae & Tulsi & Leaf & Cold, Cough, Bronchitis \\
\hline Paederia cruddasiana & Rubiaceae & Gandabhadali & Leaf & Abdominal pain, diarrheoa \\
\hline Passiflora foetida & Passifloraceae & Jhumka lata & Whole plant & Diabetes \\
\hline Peperomia pellucida & Piperaceae & Pipul & Whole plant & Asthma, Arthritic pain \\
\hline Persicaria hydropiper & Polygonaceae & Bishkatali & $\begin{array}{l}\text { Leaf, seed, } \\
\text { root }\end{array}$ & Allergy, Stomach pain \\
\hline $\begin{array}{l}\text { Phyllanthus } \\
\text { reticulatus }\end{array}$ & Euphorbiaceae & Chitki & $\begin{array}{l}\text { Root, stem. } \\
\text { bark }\end{array}$ & Malaria \\
\hline Rauvolfia serpentina & Apocynaceae & Swarpagandha & $\begin{array}{l}\text { Root, bark, } \\
\text { leaf }\end{array}$ & $\begin{array}{l}\text { Hypertension, Mental } \\
\text { disorder }\end{array}$ \\
\hline Scoparia dulcis & Scrophulariaceae & Bandhone & Whole plant & Malaria, Diarrhoea \\
\hline Senna alata & Caesalpiniaceae & Dadmordon & Leaf & Ringworm, Constipation \\
\hline Spilanthes calva & Asteraceae & Surya kannya & Leaf, flower & Toothache \\
\hline Stephania japonica & Menispermaceae & Nimuka & Root, leaf & $\begin{array}{l}\text { Dysentery, Diarrhoea, } \\
\text { Fever }\end{array}$ \\
\hline Swietenia mahagoni & Meliaceae & Mehogoni & Stem bark & Diabetes \\
\hline Tamarindus indica & Caesalpiniaceae & Tentul & $\begin{array}{l}\text { Fruit, leaf, } \\
\text { bark }\end{array}$ & $\begin{array}{l}\text { Hypertension, Tonic, } \\
\text { Asthma }\end{array}$ \\
\hline Toona ciliata & Meliaceae & Toon & Bark, flower & Menstrual disorders \\
\hline Vitex nigundo & Verbenaceae & Nishinda & Leaf, fruit & $\begin{array}{l}\text { Ulcer, Rheumatism, } \\
\text { Asthma }\end{array}$ \\
\hline Ziziphus mauritiana & Rhamnaceae & Boroi & $\begin{array}{l}\text { Fruit, bark, } \\
\text { root }\end{array}$ & Scabies, Diarrhoea, Fever \\
\hline
\end{tabular}

The study reveals that herbs are represented by 118 species (55\%), shrubs by 32 species (15\%), trees by 50 species (23\%) and climbers by 16 species (7\%). This pattern of habit groups were the indication of the progressive succession of the vegetation. The study also shows that 113 species are perennial and 103 are annual. 
In the study area, the most common homestead species are Hibiscus rosa-sinensis, Ocimum tenuiflorum, Averrhoa carambola, Swietenia mahagoni etc. Other commonly found species in the homestead are Areca catechu, Achyranthes aspera, Alocasia macrorrhizos, Barringtonia acutagula, Calotropis gigantea and Clerodendrum viscosum. Some climbers such as, Cayratia trifolia, Stephania japonica etc. grow with the support of homestead trees. Cuscuta reflexa observed on the homestead trees as a parasite. Commonly growing roadside plants are Eucalyptus citriodora, Phyllanthus reticulatus, Glycosmis pentaphylla, Heliotropium indicum, Solanum nigrum, Croton bonplandianum, Leucus aspera, Cassia fistula etc. The floating macrophytes which are common in the study area include Pistia stratiotes, Lemna perpusilla, Eichhornia crassipes etc. Shallow water bodies support the taxa like Nymphaea nouchali, Ipomoea aquatica, etc. Of the recorded species from Lalpur Upazila, 158 were commonly found throughout the study area, 39 species were very common, whereas 19 species were found rare. Some of the rare plants in Lalpur Upazila as revealed from the field investigation are Andrographis paniculata, Averrhoa carambola, A. bilimbi, Bacopa monnieri, Barringtonia acutangula, Bombax insigne, Careya arborea, Dioscorea alata, Lannea coromandelica, Passiflora foetida, Paederia cruddasiana, Toona ciliata, Trema orientalis, Trichosanthes tricuspidata and Typha domingensis. Among them Andrographis paniculata and Bombax insigne are listed as threatened in the Red List of vascular plants of Bangladesh (Khan et al. 2001).

The present study has identified some threats to the angiospermic flora of Lalpur Upazila, viz. habitat destruction, industrialization, urbanization and over-exploitation of medicinal plants. A number keystone species including medicinal plants might disappear in near future from the study area due of these threats. Therefore, necessary steps should be undertaken to conserve the plant species along with habitat protection. Some of the important measures to be undertaken to conserve plant diversity include: protection of habitat degradation, preparation of distribution map of the species of the studied area, building public awareness for preservation of plant diversity, conservation of medicinal, rare and threatened species, and documentation of traditional usage of the medicinal plants. In conclusion, a long-term monitoring program on the existing flora of Lalpur Upazila of Natore district along with their conservation through both ex situ and in situ approaches need to be adopted.

\section{References}

Ahmed, Z.U., Z.N.T. Begum, M.A. Hassan, M. Khondker, S.M.H. Kabir, M. Ahmed, A.T.A. Ahmed, A.K.T. Rahman and E.U. Haque (eds.) 2008-2009. Encyclopedia of Flora and Fauna of Bangladesh, Vols. 6-10, 11, 12. Asiatic Society of Bangladesh, Dhaka. 
Dassanayake, M.D. and F.R. Fosberg (eds.) 1980-1991. A Revised Handbook to the Flora of Ceylon, Vols. 1-6. Amerind Publishing Co. Pvt. Ltd., New Delhi, India.

Heywood, V. 2004. Modern approaches to floristics and their impact on the region of SW Asia. Turk. J. Bot. 28: 7-16.

Hooker, J.D. 1872-1897. The Flora of British India. Vols. 1-7. Bishen Singh Mahendra Pal Singh, Dehra Dun, India.

Huq, A.M. 1986. Plant Names of Bangladesh. Bangladesh National Herbarium, BARC, Dhaka, Bangladesh, pp. 1-289.

Hyland, B.P.M. 1972. A technique for collecting botanical specimens in rain forest. Flora Malesiana Bulletin 26: 2038-2040.

Khan, M.S. (ed.) 1972-1987. Flora of Bangladesh. Fasc. 1-39. Bangladesh National Herbarium, Dhaka.

Khan, M.S. and A.M. Huq. 2001. The vascular flora of Chunati Wildlife Sanctuary in south Chittagong, Bangladesh. Bangladesh J. Plant Taxon. 8(1): 47-64.

Khan, M.S. and F. Banu. 1972. A taxonomic report on the angispermic flora of Chittagong Hill Tracts - 2. J. Asiatic Soc. Bangladesh 17(2): 63-68.

Khan, M.S. and M.A. Hassan. 1984. A taxonomic report on the angiospermic flora of St. Martin's Island. Dhaka Univ. Studies, Part B. 32(1): 76-78.

Khan, M.S. and M.M. Rahman (eds.) 1989-2002. Flora of Bangladesh. Fasc. 40-53. Bangladesh National Herbarium, Dhaka.

Khan, M.S., M.M. Rahman, A.M. Huq, M.M.K. Mia and M.A. Hassan. 1994. Assessment of biodiversity of Teknaf game reserve in Bangladesh focusing on economically and ecologically important plants species. Bangladesh J. Plant. Taxon. 1(1): 21-33.

Khan, M.S., M.M. Rahman and M.A. Ali. (Eds.) 2001. Red Data Book of Vascular Plants of Bangladesh. Bangladesh National Herbarium, Dhaka. 179 pp.

Rahman, M.O. and M.A. Hassan. 1995. Angiospermic Flora of Bhawal National Park, Gazipur (Bangladesh). Bangladesh J. Plant Taxon. 2(1\&2): 47-79.

Rahman, M.O. and M.A. Hassan. 2017. New angiospermic taxa for the flora of Bangladesh. Bangladesh J. Plant Taxon. 24(2): 165-171.

Rahman, M.O. and M.T. Alam. 2013. A taxonomic study on the angiosperm flora of Trishal Upazila, Mymensingh. Dhaka Univ. J. Biol. Sci. 22(1): 63-74.

Rahman, M.O., R.T. Antara, M. Begum and M.A. Hassan. 2012. Floristic diversity of Dhamrai upazila of Dhaka, Bangladesh with emphasis on medicinal plants. Bangladesh J. Bot. 41(1): 71-85.

Rahman, M.O., M. Begum and M.W. Ullah. 2013. Angiosperm flora of Sadar Upazila of Munshiganj district, Bangladesh. Bangladesh J. Plant Taxon. 20(2): 213-231.

Rashid, M.E. and M.A. Rahman. 2011. Updated nomenclature and taxonomic status of the plants of Bangladesh included in Hook. f., The Flora of British India: Volume-I. Bangladesh J. Plant Taxon. 18(2): 177-197.

Rashid, M.E. and M.A. Rahman. 2012. Updated nomenclature and taxonomic status of the plants of Bangladesh included in Hook. f., The Flora of British India: Volume-II. Bangladesh J. Plant Taxon. 19(2): 173-190.

Siddiqui, K.U., M.A. Islam, Z.U. Ahmed, Z.N.T. Begum, M.A. Hassan, M. Khondker, M.M. Rahman, S.M.H. Kabir, M. Ahmad, A.T.A. Ahmed, A.K.A. Rahman and E. U. Haque. (eds.) 2007. Encyclopedia of Flora and Fauna of Bangladesh, Vol. 11. Angiosperms: Monocotyledons. Asiatic Society of Bangladesh, Dhaka.

The Plant List, 2013. The Plant List, a working list of all plant species. Version $1.1<\mathrm{http}: / / \mathrm{www}$. theplantlist.org/>. Accessed on 21 October 2018.

TROPICOS, 2017. Tropicos.org. <www.tropicos.org>. Missouri Botanical Garden, Saint Louis, Missouri, USA. Accessed on 21 October 2018. 
Tutul, E., M.Z. Uddin, M.O. Rahman and M.A. Hassan. 2010. Angiospermic flora of Runctia Sal forest, Bangladesh-II. Magnoliopsida (Dicots). Bangladesh J. Plant Taxon. 17(1): 33-53.

van Valkenburg, J.L.C.H. and N. Bunyapraphatsara (eds.) 2002. Plant Resources of South-East Asia, No. 12(2). Medicinal and Poisonous Plants 2. Prosea Foundation, Bogor, Indonesia, pp. 1-782.

Yusuf, M., J.U. Chowdhury, M.N. Haque and J. Begum. 2009. Medicinal Plants of Bangladesh. Bangladesh Council of Scientific and Industrial Research, Chittagong, Bangladesh, pp. 1-794.

(Revised copy received on 16.03.2019) 